\title{
THE EFFECT OF INTERNALIZED OF VALUES ORGANIZATIONAL CULTURE IN RELATION TO ORGANIZATIONAL COMMITMENT: PT. PERTAMINA (PERSERO) UNIT II DUMAI REFINERY, INDONESIA CASE STUDY
}

\author{
Syarifah Farradinna, Fatimah Omar, Fatimah Wati Halim \\ School of Psychology and Human Development, \\ Social Science and Humanities Faculty, National University of Malaysia, 43000
}

\begin{abstract}
.
The purpose of this study was to develop and test models of the internalization value of organizational culture that appears to determine the characteristics of organizational commitment among employees of PT. Pertamina (Persero) Unit II Dumai Refinery, Indonesia. The internalized of values organizational culture was related to the organizational commitment dimension (affective, normative, and continuance). Likewise, organizational commitment was correlated to the internalized of values organizational culture (clean, competitive, confident, customer focused, commercial, and capable). It seems that higher internalized of values organizational culture associated with higher of commitment in organization, vice versa. Internalized of values organizational culture dimensions interaction showed no greater value than organizational commitment based on sociodemographic variables, this shows demographic factors should know better human resources and cultural values.
\end{abstract}

\section{Keyword:}

values, organizational culture, organizational commitment

\section{Council for Innovative Research}

Peer Review Research Publishing System

Journal of Social Science Research

Vol.3, No.3

editor@jssronline.com

www.cirworld.com, www.jssronline.com, 


\section{INTRODUCTION}

PT. PERTAMINA EP (Perusahaan Pertambangan Minyak dan Gas Bumi Negara or State Oil and Natural Gas Mining Company) is engaged in business activities in the upstream sector of the oil and gas fields, including exploration and exploitation, corporation based in Jakarta. PT. PERTAMINA EP also performs other supporting business activities that directly or indirectly support the main areas of business activity. Nowadays, PT PERTAMINA EP carrying out the transformation socializes culture change in the organization, as far as transformational the organizational culture lead to perform beyond expectations in an organizational setting.

For more than 30 years, Pertamina has Carried out the government's mandate to support Indonesian economy growth at the start era monopoly: fueling the economic growth on 1971 to 1999 , the economy entered the era of post-crisis transition year rule from 2000 to 2005, until the open era: 2006-onwards. PT. Pertamina realized by making changes to the culture that has been believed so far, of the centralization of the country's economic and political power to Democratization and decentralization-with 'transitional' instability. PT. Pertamina began to shift culture (promoting efficiency and cost awareness, customer focus, support the transformation, openness to practice best practices and external employees, and the view of the leader as a role model (Pertamina, 2009). Pertamina embed cultural values that provide an overview of the organization in the implementation of values to an individual's beliefs relating to the commitments reflected in the pattern of behavior in organizations. Cultural values have the potential to affect an individual's sense of organizational commitment, which contains socializing that can be implemented to the way of thinking and behaving. This is due to the organization vulnerable to changes that led to the risk of loss of resources and employee commitment in supporting the organization's culture rhetoric (Whiteley et al 2012).

Meanwhile, another view revealed that the value is hard to teach people about the awareness and commitment. Although they tried to learn, the values of organizational culture unable to be forced, therefore, the organization needs to provide the opportunity to internalize the cultural values (Marquise \& Huston 1996) in the organization develop the awareness to environmental changes, a bit of his time in a lifestyle improvement, emphasis on the fast growing financial difficulties and uncertainty (Handel \& Gefen-Liban 2003). Internalization of cultural values is possible when individuals learn and appreciate the values that are applied by means of a mechanism of action (Michailova \& Minbaera 2012), share the perception and orientation in a dynamic and sensitive to influences from outside the organization (Berson et al., 2008). The purpose of this study was to develop and test models of the internalization value of organizational culture that appears to determine the characteristics of organizational commitment among employees of PT. Pertamina (Persero) Unit II Dumai Refinery, Indonesia. Beside that, researcher find it important to examine the relationship between internalization of the cultural values of the organization and commitment to the organization. Psychologists of work has been pay attention to the internalization of the values of the existing organizational culture in terms of workplace behavior and employee commitment towards the organization.

\section{LITERATURE REVIEW}

The Internalization Values Of Organizational Culture

Values is a fundamental aspect of the organization, or individual (Katz \& Kahn 1978). Values as the basis for organisational culture, and then conducted preferences in determining the behavior of individuals within the organization (Howell et al 2012; van Vuuren, Veldkamp, de Jong and Seydel 2008). Described organizational culture as the core substance that has values in it (Schein 1992), and finnaly, values is described as an important part of the culture of organization (Issac et al 2004).

Culture is shared of knowledge, meaning that members of the organization understand that there is a culture within the organization, which consists of rules, norms, and values of the organization. Required organizational culture as shared social knowledge that shape the attitudes and behaviors of employees, by creating a system of control over employees (Qolquitt et al, 2011). The scholars believe the values of individual personality is the most important for the organization in influencing their decisions for the organization. Culture is important in creating value and positioning system, the system according to which workers may be a factor in the results such as job satisfaction and organizational commitment (Farrell, 1993). In theoretical reveal the same thing that a view on work and organization related to job satisfaction, organizational commitment and job performance (Mayer \& Allen, 2002).

O'Reilly \& Tushman (2004) defined culture highly essential to develop and maintain the level of intensity and dedication of the workers who often characterize a successful organization. Hence, culture is difficult to change because there is resistance to that valued and defended (Sempane et al., 2002). Thus, the organization determines how to do business and as a result affects the success of the organization (O'Reilly \& Tushman, 2004). Choi, Martin., \& Park (2008); Schein (1992) describes the definition of organizational culture as the values that have been believed and trusted by individuals within an organization. Organizational culture contains a set of norms and values of an organization that affects the organization's members (Champoux 1996). The values adopted as a basic member organization stand, and besides that it also predicts how that can be done by members of the organization in decision-making and act.

Organizational culture value used to differentiate individual personal values and values that must be believed individual to the organization (Berson 2008). Which also, personal values are standard values stable and realized by the individual (Schein 1992). The internalized of values organizational culture dimension will indicate the high levels of clean, competitive, confident, customer focused, commercial and finally capable (Annual report PT. Pertamina (persero), 2012), Described as follow: 
Clean (professionally managed, avoid conflict of interest, never tolerate bribery, respect trust and integrity based on good corporate governance principles), Competitive (able to compete both regionally and itenationally, supoort growth through investment, build cost effective and performance oriented culture), confident (involve in national economic development, as pioneer in state owned enterprises' reformation, and buld national pride), cutomer focused (focus on customers and commit go give the best service to customers), commercial (create added values based on commercial oriented and make decisions based on fair business principles), capable (managed by professional, skilled, and high quality leaders and workers, committed to buld research and development capability)

\section{Commitment Organization}

Initially, the focus of commitments related to the behavior, the theory further determines the commitment in terms of attitudes. Commited such an attitude is a condition in which individuals identify goals and desire to maintain membership of the organization in order to facilitate the organization's goals (Mowday et al., 1979). He added commitment expands more slowly, but consistently over time compared to the satisfaction has been found also that the satisfaction to become unstable. It is assumed to reflect a more rapid response to specific aspects of the work environment.

Over two decades of attention given to the development of the theory of organizational commitment as a major focus of research. For instance, the commitment is built on the overall variability of multidimensional commitment; antecedent, correlates, and consequences (Meyer et al., 2002). However, the model components (antecedents, correlates, and consequences), overlapped with other multidimensional conceptualization. Three forms of psychological linkage between resources and their organization, namely; as the basis of assessment of compliance employees received an award from the organization, the process of identifying the employees a sense of pride in its relationship with the organization, and finally internalization of the values and norms of the organization's employees (Rego et al., 2004).

Another approach mentioned affective commitment occurs when employees are directly involved in the relationship and valuerelevance measures applied by the organization. Continuance commitment is described as employees stay afloat and realize no one organization other than the current ones. Normative commitment as well as the development process of internalization of norms and values of the organization, conduct employee fringe benefits, and acceptance of all forms of employee psychological contract requirements to the organization (Allen \& Meyer 1996, 2000; Meyer et al., 2002; Meyer \& Herscovitch 2001). Many factors influence organizational commitment, including emotional attachment, identification with, and involvement in the organization, employees' assessment, and feeling obligated to the organization (Mayer \& Allen, 1991).

\section{THEORITICAL FRAMEWORK}

The framework is related to the culture of the organization as a whole sense, beliefs, and values that are shared with members of the organization, through the internalization of culture values of individuals transferred from outside to inside the organization, which then creates an individual's mental permanently. Organizational culture is also described as bureaucracy related to tasks oriented control (Lasley 1999; Ninsiima 2003). Meanwhile, internalized organizational values are essential component of organizational culture (Schein 2004).

Internalization is a process in which individual perform a transition from the outside to the personal object (Ekwutosi \& Moses 2013). Therfore, internalization of cultural values in the organization covers merger and the process of identifying an internal mechanism created to permanently mental objects and events in the organization, thus the relationship between the values of organizational culture and organizational commitment is a response to the behavior of individual in the study to analyze the process and the perception of individual behavior persist or leaving the workplace. Internalization of the organization's perceived values is directly proportional directly related to a positive attitude towards work, such as commitment (Howell et al 2012; Posner 1992), which subsequently became the most decive values in assessing organisational culture.

The hypothesis will be tested using data from a set of questionnaires that measure employee perceptions of PT. Pertamina to the environment faced the current and the future of their organizations. The results of the correlation tests, regression and ttest are presented, and implications for research and adaptation for executive leaders, along with other findings. Employee perceptions of the implementation of organizational cultural values found are poorly understood. Meanwhile, the cultural values of the organization serves as an antecedent practice in the act as a mediator in the relationship between work and resource performance, for instance, the commitment of employees to the organization, decreased to leave work and increase productivity (Amos \& Weathington 2008; Howell et al 2012; van Vuuren et al 2008)

\section{METHOD}

\section{Sampel}


Researcher consisted of 143 Officer of PT. Pertamina (Persero) Refinery Unit II Dumai, Indonesia in five departments (Human resources, IT, Financial, Procurement and legal). All participants were full-time employees. (Table.1 Demographic characteristics of sample) Most respondents were Male (74.1 percent) in mean of gender is 1.26, SD =0.439. Based on classification by job type was as follows: 7 percent in IT division, 35 percent in Financial division, 23.1 percent in procurement division, 24.5 in Legal division, and 10.5 percent in Human Resources division. The mean classification by job type showed 2.97 and $S D=1.141$. Meanwhile, the mean of the length of working in years showed $15.38, S D=10.734$. The respondents had tenures 3-10 years ware measured 49.7 percent, only 18.2 percent had tenures between 11-21 years, and the rest of the respondents had tenures $22-32$ years.

Table. 1

Demographic characteristics of sampel

\begin{tabular}{lcccc}
\hline & Mean & SD & Frequency & $(\%)$ \\
\hline Gender & 1.26 & 0.439 & & \\
Male & & & 106 & 74.1 \\
Female & & & 37 & 25.9 \\
Total & & & 143 & 100
\end{tabular}

\section{Instruments}

There are three instruments were selected which can appropriately measure the constructs this study. The questionnaires be using 5 likert-point scales ranging from $5=$ strongly agree to $1=$ strongly disagree. The participants were invited to fulfill their demographic scale, internalized of values organizational culture developed and validated based on core values (data laporan tahunan 2011) of PT. Pertamina (persero) namely; clean (integrity), competitive, confident, customer focused, commercial, capable. The coefficient alpha for this questionnaire was 0.942. Questionnaire containing 42 items selected. Organizational commitment questionnaire containing 29 items selected from an instrument developed by Mayer and Allen (1990), and containing coefficient alpha was 0.941. Higher scores both questionnaires indicated higher internalized of values organizational culture and organizational commitment variables.

\section{RESULT}

The reliability of the measurements was assessed by calculating the reliability coefficient, Cronbach alpha, for each measurement scales components of organizational commitment scale, which consists of affective commitment (0.483), normative commitment (0.858) and continuance commitment (0.828). Similarly, the Cronbach alpha value on the five dimensions of internalization of organizational culture, which is clean (0.769), competitive (0.555), confident (0.784), customer focused $(0,711)$, commercial $(0.868)$, and capable $(0.719)$. In addition, the correlation between the internalization of organizational culture and organizational commitment as a whole showed a strong correlation of $r=0.810, p<0.000$. Table 2 presents descriptive statistics of the variables and the correlation among them.

Table 2

Mean, Standard Deviation, and Correlation of the study variables $(n=143)$

\begin{tabular}{|c|c|c|c|c|c|c|c|c|c|c|}
\hline Variables & Mean & SD & 1 & 2 & 3 & 4 & 5 & 6 & 7 & 8 \\
\hline 1. Affective & 41.68 & 4.7 & & & & & & & & \\
\hline 2. Normative & 42.85 & 4.719 & $0.867^{\star *}$ & & & & & & & \\
\hline 3. Continuance & 36.75 & 4.306 & $0.793^{* *}$ & $0.822^{\star *}$ & & & & & & \\
\hline 4. Clean & 36.86 & 3.860 & $0.698^{\pi x}$ & $0.726^{\pi x}$ & $0.588^{\star x}$ & & & & & \\
\hline 5. Competitive & 23.83 & 2,493 & $0.662^{\star \star}$ & $0.666^{\star *}$ & $0.575^{\star \star}$ & $0.661^{\star *}$ & & & & \\
\hline 6. Confident & 28,22 & 3,131 & $0.678^{\star *}$ & $0.698^{* *}$ & $0.629^{* *}$ & $0.778^{\star *}$ & $0.650^{* *}$ & & & \\
\hline 7. Customer & 23,91 & 2,651 & $0.692^{\star \pi}$ & $0.675^{x \rtimes}$ & $0.641^{\star x}$ & $0.689^{* x}$ & $0.687^{x \times}$ & $0.729^{\star \pi}$ & & \\
\hline
\end{tabular}




\author{
Focused \\ 8. Commercia \\ 9. Capable \\ 33,21 \\ $\begin{array}{ll}3,911 & 0.707^{* *} \\ & 2,109\end{array}$ \\ $0.699^{* *} \quad 0.570^{* *}$ \\ $0.733^{\text {*x }}$ \\ $0.752^{\text {** }}$ \\ $0.765^{* *}$ \\ $0.711^{*}$ \\ ${ }^{* *}$ correltion is significant at the $p \leq 0.01$ (2-tailed)

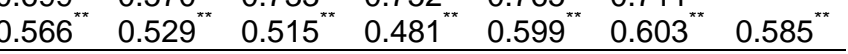

Based on table 2 presents the correlations among internalized of values organizational culture and organizational commitment. This comparison shows that all dimensions of internalized of values organizational culture (clean, competitive, confident, customer focused, commercial and capable) in PT. Pertamina (persero) data are highly correlated with organizational commitment (affective, normative and continuance). The highest correlation obtained in this study were between normative and affective organizational commitment $\left(r=0.867^{* *}\right)$. Inter-correlations, and reliability of the research variables show that dimensions of internalized of values organizational culture were positively correlated with dimensions of organizational commitment.

The hypothesis proposed in this study also found significant differences in the internalized of values organizational cultureand organizational commitment based on gender variable. T-test was used in this analysis. As shown in table 3, the independent sampel mean t-test of Male in internalized of values organizational culture showed highest than Female employees mean t-test $(M=171.31, S D=15.868$ by Men; $M=165.54, S D=14.184$ by Female). It was inferred that Male employees interfered more internalized of values organizational culture than Female employees. Therefore, There was in different organizational commitment between Male $(M=122.10, S D=15.868)$ and Female $(M=118.92, S D=16.980)$.

Table 3

Independent sampel t-test for gender variable in Internalized of values organizational culture and Organizational commitment

\begin{tabular}{|c|c|c|c|c|c|}
\hline Gender & & $\mathrm{N}$ & Mean & Std. Deviation & $\begin{array}{l}\text { Std. Error } \\
\text { Mean }\end{array}$ \\
\hline Internalized of & Male & 106 & 171.31 & 15.868 & 1.541 \\
\hline $\begin{array}{c}\text { Values } \\
\text { organizational } \\
\text { culture }\end{array}$ & Female & 37 & 165.54 & 16.980 & 2.791 \\
\hline Organizational & Male & 106 & 122.10 & 12.411 & 1.205 \\
\hline Commitment & Female & 37 & 118.92 & 14.184 & 2.332 \\
\hline
\end{tabular}

Table 4

Independent sampel t-test for gender variable in Internalized of values organizational culture and Organizational commitment

\begin{tabular}{|c|c|c|c|c|c|c|c|c|c|}
\hline \multirow[t]{2}{*}{ Gender } & $\begin{array}{l}\text { Leven } \\
\text { equality }\end{array}$ & $\begin{array}{l}\text { test for } \\
\text { varianc }\end{array}$ & \multicolumn{5}{|c|}{ t-test for equality of means } & \multicolumn{2}{|c|}{$\begin{array}{c}95 \% \text { confidence interva } \\
\text { of the difference }\end{array}$} \\
\hline & $\mathrm{F}$ & Sign & $\mathrm{t}$ & $\mathrm{df}$ & Sign & Mean & Std. error & Lower & Upper \\
\hline Commitment & & & & & 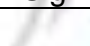 & & & 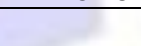 & \\
\hline $\begin{array}{l}\text { Equal variance } \\
\text { assumed }\end{array}$ & 1.186 & 0.278 & 1.294 & 141 & 0.198 & 3.185 & 2.461 & -1.680 & 8.050 \\
\hline $\begin{array}{l}\text { Equal variances not } \\
\text { assumed }\end{array}$ & & & 1.213 & 56.431 & 0.230 & 3.185 & 2.625 & -2.073 & 8.442 \\
\hline
\end{tabular}

Multi regression analyses were used to test between the internalized of values organizational culture with organizational commitment variables. Table 5 present result predicting the internalized of values organizational culture were statistically significant interaction on affective $(\beta=0.791, F=235.932, p<0.001)$, normative $(\beta=0.796, F=243.505, p<$ $0.001)$, and continuance $(\beta=0.694, F=130.955, p<0.001)$ organizational commitment. Meanwhile, results predicting overall organizational commitment were statistically significant to the internalized of values organizational culture dimensions; clean $(\beta=0.715, F=147.209, p<0.001)$, competitive $(\beta=0.676, F=118.592, p<0.001)$, confident $(\beta=0.711, F=144.374, p<$ $0.001)$, customer focused $(\beta=0.712, F=144.903, p<0.001)$, commercial $(\beta=0.494, F=137.521, p<0.001)$, capable $(\beta=$ $0.594, F=76.784, p<0.001)$.

Table 5 also shows the results of the model predicting overall the internalized of values organizational culture significant influence on organizational commitment. We noted that $65.6 \%$ to have predictor effect in Internalized of values organizational culture to organizational commitment of the total variance $\left(\mathrm{R}^{2}=0.656, F=268.805, p<0.001\right)$.

Table 5

Results of multiple regression analysis

\begin{tabular}{lllllll}
\hline Criterion variables & Predictor variables & $\mathrm{R}^{2}$ & $\mathrm{~F}$ & $t$ & Beta \\
\hline
\end{tabular}




\begin{tabular}{llllll}
\hline Affective & Internalized of values & $0.262^{* *}$ & 235.932 & 15.360 & 0.791 \\
Normative & organizational culture & $0.633^{* *}$ & 243.505 & 15.605 & 0.796 \\
Continuance & & & 130.955 & 11.444 & 0.694 \\
& & $0.511^{* *}$ & 147.209 & 12.133 & 0.715 \\
Clean & & $0.457^{* *}$ & 118.592 & 10.890 & 0.676 \\
Competitive & Organizational & $0.506^{* *}$ & 144.374 & 12.016 & 0.711 \\
Confident & $0.507^{* *}$ & 144.903 & 12.038 & 0.712 \\
Customer Focused & commitment & $0.494^{* *}$ & 137.521 & 11.727 & 0.703 \\
Commercial & & $0.353^{* *}$ & 76.784 & 8.763 & 0.594 \\
Capable & & & & \\
& & & & & \\
Commitment & Internalized of values & $0.656^{* *}$ & 268.805 & 16.395 & 0.810 \\
\hline
\end{tabular}

\section{CONCLUSION}

The findings of this study showed that the significant relationship of the internalized of values organizational culture and organizational commitment supports our hypotheses and empirically framework the relationship between variables. Benerjee (2008); Hostede (2001) study about culture refers to a set of values, ideas and symbols meaningful help individuals communicate, interpret, and evaluate the organization's members. Culture consisting of shared values, assumptions, and understanding of the subject and purpose instilled in as part of the organization's members (Deresky , 2003).

The internalized of values organizational culture was related to the organizational commitment dimension (affective, normative, and continuance). Likewise, organizational commitment was correlated to the internalized of values organizational culture (clean, competitive, confident, customer focused, commercial, and capable). It seems that higher internalized of values organizational culture associated with higher of commitment in organization, vice versa. McKinnon et al (2003) with respect to support for values of organizational culture in affecting outcomes, correlated to commitment. The closer an individual to prefere and perceive the values of organization culture, the thigher the organizational commitment, job satisfaction, propensity to remain, and information sharing. Choi's et al (2008) studied show the positive impact of the culture on commitment organizational, the importance of personal values is presumption of commitment.

Normative dimension shows the results of a large-scale interaction value compared to the other dimensions of commitment ot the internalized of values organizational culture, whereas continuance commitment shows values less interactions. In contrast with the results of the resarch Ortega-Parra \& Sastre-castillo (2013) which shows a more prominent affective dimension showed a strong relationship with the values and behavior of individulas within the organization. However, in accordance to studies acquired Ghosh (2010) found that continuance commitment as a bottom-line values, wich related to the concepts of economic and efficiency in the management of the organization. Whichever, internalized of values organizational culture dimensions interaction showed no greater value than organizational commitment based on sociodemographic variables, this shows demographic factors should know better human resources and cultural values. This relates to a provious study (Ortega-Parra \& Sastre-castillo 2013; Noordin et al 2011) that the perception of a conflict of different cultures to the value of the organization, for example, whether male employees better in the internalized of values organizational culture and more commited to the organization than female. Addiotional, if the employee has worked less likely to stop working than others.

\section{REFERENCES}

Allen, N. J., \& Meyer, J. P. (1996). Affective, continuance, and normative commitment to the organization: An exmination of construct validity. Journal of Vocational Behavior, vol. 49 (3), pp. 252-276

Allen, N. J., \& Meyer, J. P. (2000). Construct validation in organizational behavior research: The case of organizational commitment. In R.D. Goffin \& E. Helmes (eds), Problems and solution in human assessment: Honoring Douglas N. Jackson at seventy: pp.285-314. Norwell, M.A: Kluwer Academic Pub

Amos, E. A., \& Weathington, B. L. (2008). An analysis of the relation between employee-organization value congruence and employee attitudes. Journal Psychology, vol 142 (6), pp. 615-631

Benerjee, S. (2008). Dimensions of Indian culture, core cultural values and marketing implications: An analysis. Cross Cultural Management: An International Journal, vol. 15 (4), pp. 367-378

Berson, Y., Oreg, S., \& Dvir, T. (2008). CEO values, organizational culture and firm outcomes. Journal Of Organizational Behavior, vol. 29, pp.615-633

Champouz, J. E. (1996). Organizational Behavior: Integrating Individuals, Groups, And Processes. St. Paul, MN: West Pub Co

Choi, S. Y., Martin, J. J., \& Park, M. (2008). Organizational culture and job satisfaction in Korean professional baseball organizations. International Journal of Applied sports Sciences, vol. 20 (2), pp. 59-77

Colquitt, J. A., LePine, J. A., \& Wesson, M. J. (2011). Organizational behavior: improving performance and commitment in the workplace. McGraw-Hill school education group

Deresky, H. (2003). International Management: Managing Across Borders and Cultures, $4^{\text {th }}$ ed. Prentice Hall, Upper saddle River. NJ 
Farrell, S. M. (1993). Organizational cultures and values as they impact on job satisfaction and organizational commitment. Thesis. Applied behavior science program, University of Wright State

Ghosh, S. K. (2010). Perceived organizational values and commitment to organizationa. The Indian Journal of Industrial Relations, vol. 45 (3), pp. 437-445

Hendel, T., \& Gefen-Liban, D. (2003). Getting ready for the future: assessing and promoting graduate students' organizational values. Nurse Education Today, vol. 23, pp.482-491

Hostede, G. (2001). Culture's Consequences. Sage Pub, Thousand Oaks. CA

Howell, A., Krik-Brown, A., \& Cooper, B. K. (2012). Does congruence between espoused and enacted organizational values predict affective commitment in Australian Organizations? The International Journal of Human Resource Management, vol 23 (4), pp. 731-747

Lasley, C. (1999). Employee empowermen in services: A framework for analysis. Personal review, vol. 28, pp. 1-19

Marquis, B. L., \& Huston, C. J. (1996). Leadership roles and management in nursing. Lippincott, Philadelphia

Meyer, J. P., \& Allen, N. J. (1991). A three-component conceptualization of organizational commitment. Human Resource Management Review, vol. 1, pp. 61-89

Meyer, J. P., Stanley, D. J., Herscovitch, L., \& Tololnytsky, L. (2002). Affective, continuance, and normative commitment ot the organization: A Meta-analysis of antecedents, correlates, and consequences. Journal of Vocational Behavior, vol. 61, pp. 20-52

Michailova, S., \& Minbaeva, D. B. (2012). Organizational values and knowladge sharing in multinational corporations: the danisco case. International Business Review, vol. 21, pp.59-70

Mowday, R. T., Steers, R. M., \& Porter, L. W. (1979). The measurment of organizational commitment. Journal of Vocational Behavioer, vol. 14, pp. 224-247

Ninsiima, K. J. (2003). Competencies, empowerment, perceived justice, task performance and organizational citizenship behavior in Uganda revenue authority. Unpublised Masters Thesis, Makerere University Kampala, Uganda

Noordin, F., Rahim, A. R., Ibrahim, A. H., \& Omar, M. S. (2011). An analysis of career stages on organizational commitment of Australian managers. International Journal of Business and Social Science, vol. 2 (17), pp. 117-126

O'Reilly, C. A., \& Tushman, M. L. (2004). The ambidextrous organization. Harvard Business Review, vol. 82, pp. 74-81

Ortega-Parra, A., \& Sastre-Castillo, M. A. (2013). Impact of perceived coporate culture on organizational commitment. Mnagement Decision, vol. 51 (5), pp. 1071-1083

Pertamina. (2009). Laporan tahunan: Pertamina transformation in changing environment. May 2009

Rego, A., Liete, R., Carvalho, T., Freire, C., \& Vieira, A. (2004). Organizational commitment: Toward different understanding of the ways people feel attached to their organizations. Management Research, vol 2 (3), pp.201-218

Schein, E. (2004). Organizational culture and leadership. San Fransico, CA: Jossey-Bass

Schein, E. H. (1992). Organizational culture and leadership, $2^{\text {nd }}$ ed. San Francisco, CA: Jossey-Bass

Sempane, M. E., Rieger, H. S., \& Roodt, G. (2002). Job satisfaction in relation to organizational culture. SA Journal of Industrial Psychology, vol. 28 (2), pp. 23-30

Van-Vuuren, M., Veldkamp, B. P., \& de Jong, M. D. T., \& Seydelm E. R. (2008). Why work?: Aligning foci and dimensions of commitment along the axes of the competing vaues framework. Personnel Review, vol. 37 (1), pp. 47-65

Whiteley, A., Price, C., \& Palmer, R. (2012). Corporate culture change: adaptive culture structuration and negotiated practice. Journal Of Workplace Learning, vol. 25, no. 7, pp.476-498

\section{Author' Biography}

Syarifah Farradinna is a Doctoral student in National University of Malaysia, and work as a lecturer in Islamic University of Riau, Psychology Faculty. Research interest area in women at work, work-family roles and domestic violence at work and family. Please send e-mail to faradina femme@hotmail.com for any question and discussion.

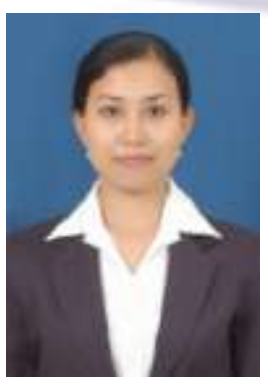

